\title{
Pénzügyi területen dolgozó értékesítők a csapattagtípus kérdöív tükrében
}

\author{
Juhász István \\ Eszterházy Károly Egyetem, Eger
}

\begin{abstract}
A TANULMÁNY CÉLJA
Olyan üzletkötői csapattagtípus felállítása - a Belbin-féle csapattagtípus kérdőív segítségével - mely megkönnyíti az üzletkötői álláshirdetésekre jelentkezők kiválasztását - illetve későbbi motiválását - a pénzügyi, biztosítási tevékenység nemzetgazdasági ág területén.
\end{abstract}

\section{MÓDSZERTAN}

A vizsgálat alanyai a jelenleg pénzügyi területen, azon belül is értékesítői munkakörben dolgozó munkavállalók. Elsősorban a bankokban, biztosítóknál, lakás-takarékpénztárakban, pénzügyi tanácsadóknál, valamint faktorcégeknél, lízingcégeknél, takarékszövetkezeteknél és tőzsdei vállalatoknál tevékenykedő értékesítők személyisége került górcső alá. A vizsgálati alanyok on-line az internet segítségével töltötték ki a kérdőíveket. A mintavétel a nem véletlen mintavételi eljárások közül, a hólabda-mintavételi eljárás révén történt. A begyüjtött adatok elemzése és kiértékelése az excel program segítségével zajlott. Megállapításra került különböző szempontok alapján, hogy mekkora a minta átlaga, valamint gyakoriságokkal és megoszlási viszonyszámokkal is dolgoztam.

\section{LEGFONTOSAB EREDMÉNYEK}

A vizsgált, pénzügyi területen dolgozó üzletkötők közül a Belbin-féle csapattagtípus kérdőívben elért eredmények alapján legtöbben a Vállalatépítő típusba (a teljes minta $26 \%$ ) tartoznak. (Magas értéket ért még el a Csapatépítő típus (19\%) és a Forrásfeltáró típus (15\%). A három típusba történő besorolás összesen a minta 60 \%-át fedi le.) A kutatásban részt vevő válaszadók - a Belbin-féle csapattagtípus kérdőív alapján - szintén ennél a három típusnál értek el a legnagyobb, 18 pont feletti értéket. Az átlageredmények tekintetében így a következő három csapattagtípus került a dobogóra: Vállalatépítő $(19,60)$, Csapatépítő $(18,78)$, Forrásfeltáró $(18,62)$.

\section{JAVASLATOK}

A pénzügyi területen tevékenykedő értékesítők kiválasztásában és motiválásában alkalmazandó Belbin-féle csapattagtípus kérdőív eredményei esetében elsősorban a következő csapattagtípusokba történő besorolást tekintsék - szükséges, de nem elégséges - pozitív feltételnek a vállalati döntéshozók: Vállalatépítő, Csapatépítő és Forrásfeltáró!

Kulcsszavak: üzletkötők, pénzügy, biztosítás, csapattagtípus kérdőív

Köszönetnyilvánitás: A tanulmány egy - 2019-ben a Miskolci Egyetem Vállalkozáselmélet és Gyakorlat Doktori Iskolájában védésre került - doktori értekezés részét képezi.

DOI: 10.15170/MM.2020.54.04.06 


\section{BEVEZETÉS INTRODUCTION}

Napjaink gazdasági körülményei és feltételei egyre komolyabb követelmények elé állítják a vállalkozásokat. A piacon elért siker már nem csak a technológián és a fizikai eszközökön múlik, hanem egyre inkább a megfelelő készségekkel, tapasztalattal, tudással és elkötelezettséggel rendelkező emberi erőforrásokon (Effron et al. 2003 in Karoliny \& Poór 2017).

Az emberi erőforrás menedzsment egyik ,kulcsa" Fombrun és munkatársai szerint (Fombrun et al. 1984) a kiválasztás. Véleményük szerint ugyanis az emberi erőforrás menedzsment esetében a hangsúly a munkavállalók kiválasztásán, értékelésén, fejlesztésén és javadalmazásán van. Definíciójukhoz kapcsolódóan: a stratégiai emberi erőforrás menedzsment ciklus kiindulópontja, valamint végső fázisa is a kiválasztás - mint olyan általános funkció - mely magában foglalja mindazokat a tevékenységeket, melyek a munkavállalók alkalmazásával, valamint a szervezeti pozíciók közötti mozgásukkal kapcsolatos (Karoliny 2009).

Szőts-Kováts (2007) szerint az illeszkedésen van a legnagyobb hangsúly: ha a HR-szakértőnek jó jelölteket sikerült toboroznia, akkor megkezdődhet a pályázók közül a legmegfelelőbb, a szervezethez és/vagy az adott munkakörhöz legjobban illeszkedő, legalkalmasabb jelölt kiválasztása. A kiválasztás során a szervezethez illeszkedés, vagy a munkakörhöz illeszkedés szempontjából való legmegfelelőbb jelölt szelekciója történik meg, attól függően, hogy milyen modellt követ a vállalat. A kiválasztási folyamatot azonban az is nehezíti, hogy Y generáció erösen nyitott a külföldi munkavállalás felé is (Szabó és tsai 2017).

Kővári $(1991,98)$ úgy fogalmaz, hogy a kiválasztás ,az a szürő, amely a felkínált munkaposztok követelményeinek és a pályázó tulajdonságainak, illetve elvárásainak megfelelését vizsgálva képes megbízható valószínűséggel rangsorolni az állás betöltésére alkalmas jelölteket.” „A kiválasztási eljárás tehát egy döntés-előkészítési folyamat, amelyben felmérik, hogy az állásra jelentkezők közül melyik jelölt, milyen valószínűséggel lesz képes az elvárt teljesítmény elérésére" (Matiscsákné 2014, 89).

Az online értékelési módszerek megjelentek a kiválasztás bővülő eszköztárában is. Miután előtérbe került az utóbbi években az élethosszig tartó tanulás (Baranyi és tsai 2019), kiemelt szerepe lett a kompetencia alapú kiválasztásnak, melyet az informatikai megoldásoknak is támogatniuk kell (pl. eseményszervezés, HR-szolgáltatói teljesítménymérés, kiválasztási tudásbázis építése, értékelési módszerek és egy teljes projekt hatékony kommunikációja terén). További elvárások közé sorolható, hogy a szoftverek a vállalatok kiválasztási elveinek és igényeinek megfelelően testre szabhatóvá tegyék azokat az értékelési szempontokat, melyek alapján a pályázókat a vállalatok el fogják bírálni. Ezen elveket a szoftverbe rugalmasan beépíthetővé kell tenni. Mindez jelentősen megkönnyíti a kiválasztás szürési fázisait, mivel így a jelentkezők jellemzőit a HR szakemberek össze tudják hasonlítani a többi pályázó jellemzőivel, valamint a munkaköri követelményekkel és így rangsort is fel tudnak állítani (Zöllei 2006). Nemeskéri (2013) azt állítja, hogy figyelembe kell venni a kiválasztási kritériumok meghatározása során a személyiségjegyekkel kapcsolatos elvárásokat is! Melyek azok, amelyek a munkatársi kapcsolatok kialakításában, a szervezeti értékek elfogadásában meghatározó értéket és szerepet képviselnek? Véleménye szerint a személyiségjegyek feltárására is kiterjedő eljárások alkalmazásakor elengedhetetlen pszichológus bevonása is a folyamatba. Ugyan a pszichológiai vizsgálati eszközök használata költségesebbé teszi a kiválasztást, de ezen költségek elenyészőek azokhoz a károkhoz képest, amelyek a nem megfelelő jelölt felvételének eredményeként a későbbiekben felmerülhetnek. A szervezetek esetében a kiválasztás eredménye ugyanis nem az, hogy valakit felvesz és alkalmaz a vállalat, hanem az, hogy vajon olyan munkavállalót vesz-e fel, aki képes lesz a munkakörét eredményesen ellátni és feladatait hatékonyan elvégezni. Mindez pedig általában csak a beillesztési folyamat végére, a próbaidő lejártára derül ki (Kozák 2015).

Véleményem szerint az értékesítés folyamata igazi csapatmunka. A folyamat során ugyanis nemcsak az ügyfél és az üzletkötő szoros, partneri együttmüködésére van szükség, hanem az értékesítőket támogató és kiszolgáló személyzet - logisztikusok, raktárosok, adminisztrátorok, értékesítést támogató back office munkatársak stb. - valamint az üzletkötők munkáját irányító vállalati vezetők, menedzserek, mentorok összehangolt tevékenységére egyaránt. A kutatás arra a kérdésre keresi a választ, hogy vajon a Belbin-féle csapattagtípusok közül mely szerep, illetve mely szerepek, azok amelyek leginkább jellemzik az ebben a csapatmunkában résztvevő üzletkötőket leginkább?

A fenti - a kiválasztás jelentőségét hangsúlyozó - gondolatokból kiindulva jelen tanulmány, ezen folyamat elősegítését tüzte ki célul oly módon, hogy a pénzügyi, biztosítási tevékenység nemzetgazdasági ágban, értékesítői pozícióban dolgozó szakemberek kiválasztására - és későbbi motivá- 
lására - fókuszált. Tette mindezt az ebben a nemzetgazdasági ágban ezidáig még - ekkora, 1000 fős mintán - nem használt Belbin-féle csapattagtípus kérdőív segítségével.

\section{A KUTATÁS MÓDSZERTANA: A VIZSGÁlAT ALANYAI, MÉ- RÉS, ADATGYÜJTÉS, ELEMZÉS ${ }^{1}$ RESEARCH METHODOLOGY: THE SUBJECTS OF THE INQUI- RY, MEASUREMENT, DATA COL- LECTION, ANALYSIS}

\section{A vizsgálat alanyai \\ The subjects of the inquiry}

A vizsgálat alanyai a jelenleg pénzügyi területen, azon belül is értékesítői munkakörben dolgozó munkavállalók. Elsősorban a bankokban, biztosítóknál, lakástakarékpénztárakban, pénzügyi tanácsadóknál, valamint faktorcégeknél, lízingcégeknél, takarékszövetkezeteknél és tőzsdei vállalatoknál tevékenykedő értékesítők személyisége került górcső alá.

\section{Mérés, adatgyüjtés \\ Measurement, data collection}

A mérés során az alábbiakban felsorolt részekböl álló kérdőív került kitöltetésre a vizsgálati személyekkel:

1. Alapadatok,

2. Belbin-féle csapattagtípus kérdőív.

A vizsgálati alanyok on-line az internet segítségével töltötték ki a kérdőíveket, kiküszöbölve így a papír alapú vizsgálatfelvételnél esetlegesen felmerülő téri- és időbeli korlátokat. Törekedtem arra, hogy a kérdőív elsősorban egyszerü ,egérhasználattal" kitölthető legyen. A kérdésekre adható válaszok többsége úgy került kialakításra, hogy a válaszadók egyszerű „kattintással” vagy a legördülő menüből történő szelektálással jelölték meg a rájuk legjellemzőbb választ. Néhány kérdésnél azonban elkerülhetetlen volt a billentyüzet használta, mint például a legmagasabb fokú szakmai végzettség vagy a munkakör pontos megnevezése (ha nem szerepelt a felsoroltak között).
Az adatgyüjtés legfontosabb ismérvei:

- $\quad$ A kérdőív 2016. december 14. és 2017. július 20. között volt kitölthetö.

- A mintavétel a nem véletlen mintavételi eljárások közül, a hólabda-mintavételi eljárás révén történt. Megkeresésre kerültek továbbá olyan nagyobb, a pénzügyi, biztosítási tevékenység nemzetgazdasági ághoz kapcsolódó szervezetek és azok tagjai közvetlen vagy közvetett formában, mint a Magyar Bankszövetség, a Magyar Biztosítók Szövetsége, az Országos Takarékszövetkezeti Szövetség, a Pénzügyi Vállalkozások Országos Egyesülete, a Magyar Lízingszövetség, a Magyar Kereskedelmi és Iparkamara, a Magyar Közgazdasági Társaság.

- 1000 fö eredményei kerültek bele a véglegesített mintába.

- A mintában szereplő üzletkötők fontosabb demográfiai adatai a következők:

- nemek szerint: a minta $62,2 \%$-a nö, $37,8 \%$-a férfi,

- $\quad$ születési idő szerint: 1933-1950 között 13 fö, 1951-1960 között 72 fö, 1961-1970 között 258 fö, 19711980 között 307 fö, 1981-1990 között 227 fö és 1991-1998 között 123 fö született,

- lakóhely szerint: megyeszékhelyen vagy megyei jogú városban 328 fó, más városban 280 fö, a fövárosban 197 fö és községben, illetve nagyközségben 195 fő él.

\section{Elemzés Analysis}

A begyüjtött adatok elemzése és kiértékelése az excel programok segítségével történt. Megállapításra került különböző szempontok alapján, hogy mekkora a minta átlaga, valamint gyakoriságokkal és megoszlási viszonyszámokkal is dolgoztam. Összehasonlításra kerültek továbbá az egyes ágazatok üzletkötőinek a csapattagtípus kérdőívben elért átlageredményei is. 


\section{A BELBIN-FÉLE CSAPATTAGTÍ- PUS KÉRDÖÍV BEMUTATÁSA PRESENTATION OF THE BEL- BIN TEAM ROLE QUESTIONNA- IRE}

A kérdőív kidolgozása Meredith Belbin nevéhez füződik, aki a hatékony vezetői teamek kialakításának egyik legismertebb szakértője. Belbin és munkatársai kutatási koncepciója az volt, hogy magasan képzett, különösen intelligens szakemberekből „szuper csapatokat”, saját elnevezésük szerint Apollo-team-eket hoztak létre (Töttös 2005). Feltételezték, hogy a különösen intelligens emberekböl kialakított csapatok a magas intellektust és elemzős készséget igénylő feladatokban az első helyen fognak végezni. Az eredmény azonban a várt hatástól igen csak elmaradva, kiábrándító lett. Az úgynevezett „Apolló” teamek a legtöbbször az utolsó helyet szerezték meg más átlagos képességü emberekből alkotott csoportok mögött.

Mi volt ennek az oka? Egyrészt az időhiány. A nagyon intelligens emberek erős kritikai érzékkel rendelkeznek, így világossá vált, hogy a megoldás helyett a szuper csapat meddő vitákra pocsékolta a rendelkezésükre álló időt és így teljesítményük adott esetben sokkal rosszabb lett, mint azoké a csapatoké, akik eredetileg gyengébb képességekkel rendelkeztek. Másrészt ezek a csapatok nagyon nehezen voltak irányíthatók, a döntéshozatalban pedig nehézkesek voltak. Elég intelligensek voltak ahhoz, hogy felismerjék a megoldások sokszínűségét egy-egy feladatban, de egymás javaslatait túlságosan is tiszteletben tartották. A konfrontációt úgy próbálták meg elkerülni, hogy álláspontjuk összeférhetetlenségét nem voltak hajlandók elismerni (Belbin 1998).

Tehát egy csoportot nem egyszerúen a kiemelkedő értelmiségủ tagok tesznek sikeressé. Felmerült a kérdés: Vajon a tiszta, valamiben kiemelkedően homogén módon eredményes csapatok visznek egy vállalatot sikerre?

Belbin az introverzió/extraverzió és a szorongás/kiegyensúlyozottság mértéke alapján négy alapvető típust állapított meg, melyeknek különféle vezetői foglalkozáscsoportokat rendelt hozzá:
- Kiegyensúlyozott extrovertáltak: fontos számukra a másokkal való együttmüködés és kapcsolattartás. Remek személyzeti vezetők és értékesítési vezetők lehetnek ebben a csoportban. (jelen tanulmány szempontjából különösen ez a csoport vált számomra érdekessé és értékessé, feltételezve azt, hogy a sikeres értékesítők ebbe a kategóriába esnek majd.)

- Szorongó extrovertáltak: leginkább az olyan munkát szeretik, ahol nyomást kell gyakorolniuk másokra és a munka gyors tempójú. Üzemvezetők, kiadók, kereskedelmi vezetők teljesíthetnek jól ebben a csoportban.

- Kiegyensúlyozott introvertáltak: olyan munkavállalók tartoznak ebbe a csoportba, akik szívesen foglalkoznak emberek egy szük csoportjával, akár hosszabb távon is jó kapcsolatokat fenntartva velük. Remek kormányzati és helyi tisztségviselők, jogtanácsosok, adminisztrátorok, ipari vállalatvezetők kerülhetnek ki közülük.

- Szorongó introvertáltak: nagy kitartással és önfegyelemmel bíró munkatársak vannak ebben a csoportban. Hosszú távú feladatokat végrehajtó kreatív szakemberek, kutatók tartozhatnak ide (Belbin 1998).

A tiszta csoportokkal folytatott kísérletek az alábbi eredményeket hozták (1. táblázat). 
1. táblázat: Belbin „tiszta” teamekkel folytatott vizsgálatának eredményei

Table 1. The results of Belbin's study with ,clean” teams

\begin{tabular}{|c|c|c|}
\hline & Extrovertált & Introvertált \\
\hline 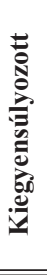 & $\begin{array}{l}\text { Jól tudnak együttmüködni; szívesen dol- } \\
\text { goznak csapatban; rugalmasak; kihasznál- } \\
\text { ják a rendelkezésre álló forrásokat; eufóri- } \\
\text { ára és nemtörődömségre hajlamosak. } \\
\text { Eredményeik összességében jók, de az } \\
\text { egyének teljesítménye nagymértékben a } \\
\text { csapattagokétól és a többi résztvevőétől } \\
\text { függ. }\end{array}$ & $\begin{array}{l}\text { Körültekintő tervezők és jó szervezők; las- } \\
\text { san reagálnak és nem veszik figyelembe, ha } \\
\text { változott a helyzet. } \\
\text { Eredményeik közepesek. }\end{array}$ \\
\hline 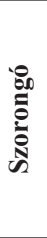 & $\begin{array}{l}\text { Vállalkozó szellemüek és dinamikusak; } \\
\text { megragadják a lehetőségeket, egészséges } \\
\text { véleményütközésre hajlamosak; figyelmük } \\
\text { könnyen elkalandozik; gyakran változtat- } \\
\text { nak álláspontot. } \\
\text { Eredményeik gyorsan változó körülmények } \\
\text { között jók, máskor megbízhatatlanok. }\end{array}$ & $\begin{array}{l}\text { Jó ötleteik vannak, de túlságosan el vannak } \\
\text { merülve saját gondolataikban; csoportban } \\
\text { nehezen müködnek együtt. } \\
\text { Eredményeik általában gyengék. }\end{array}$ \\
\hline
\end{tabular}

Forrás: Belbin 1998, 43

Belbinék minden sikeres csapatában megjelent az egyik teamszerep, a Vállalatépítő, melynek tulajdonságai a következők:

1. fegyelmezett személyiség,

2. lelkiismeretes, tisztában van kötelességeivel,

3. belülről irányított, fejlett önképpel rendelkezik,

4. makacs személyiség,

5. gyakorlatias gondolkodása mellett toleráns társaival szemben, megbízik bennük,

6. konzervatív (tiszteletben tartja a fennálló viszonyokat és gondolkodásmódot).

Megjegyzendő, hogy a „csak” Vállalatépítő típusba tartozó tagokból álló úgynevezett „,tiszta teamek" azonban nem teljesítettek az átlagtól jobban (Belbin 1998, 50-51).

„A későbbi kísérletek mind egy-egy tulajdonságot, csapatban fontos szerepet igyekeztek azonosítani, így sikerült azonosítani a kreativitásért, az erőforrások feltárásáért, az irányításért, a lelkesítésért felelő csapatszerepeket. A teszt ezt az úgynevezett elsődleges szerepet segít beazonosítani." (Töttős 2005, 32). A lehetséges szerepek a következők:

Vállalatépitő (VÁ): Kötelességtudó, kiszámítható és konzervatív. Legföbb hasznos tulajdonsága, hogy jó szervező, gyakorlatias gondolkodású, keményen dolgozik, és nagyon fegyelmezett. Megbocsátható gyengesége, hogy rugalmatlan és kevésbé fogékony az új ötletekre.
Elnök (EL): Nyugodt, biztos magában, kellő önuralommal rendelkezik. Legelönyösebb tulajdonsága, hogy képes mindenkit előítéletek nélkül és pusztán érdemei alapján értékelni. Célorientált. Mindezek mellett viszont „,csak” átlagosan kreatív és intelligens.

Serkentö (SE): Ideges, aktív, dinamikus. Legelönyösebb tulajdonsága, hogy mindig készen áll arra, hogy közbelépjen, ha tehetetlenséget, önáltatást, rossz hatékonyságot, önteltséget tapasztal. Képes küzdeni a cselekvésképtelenség, a hatékonyság hiánya ellen. Elnézhető hibája, hogy türelmetlen, hajlamos az ingerültségre és erőszakosságra.

Palánta (PA): Individualista, komoly gondolkodású, új utakat kereső. Előnyös tulajdonsága, hogy a szellem embere, képzeletgazdag, nagy tudású, kiváló értelmi képességekkel rendelkezik. Megbocsátható gyengesége, hogy gyakran a fellegekben jár, hajlamos arra, hogy a részleteket és a formaságokat figyelmen kívül hagyja.

Forrásfeltáró (FO): Jellemzői, hogy extrovertált, törekvő, érdeklődő, kommunikatív. Legfőbb hasznos tulajdonsága, hogy képes kapcsolatokat létesíteni az emberekkel, és felkutatni az új lehetőségeket. Meg tud felelni a kihívásoknak. Elnézhető hibája, hogy gyorsan elszáll a kezdeti lelkesedése, hamar elveszíti az érdeklődését.

Helyzetértékelö (HE): Józan ítéletü, megfontolt, érzelmek nélküli. Előnyös tulajdonsága, hogy jó az ítélőképessége, előrelátó, óvatos, gyakorlatias. Elnézhető hibája, hogy nem tudja lelkesíteni, motiválni sem magát, sem az embereket. 
Csapatépitö (CS): Társas hajlamú, barátságos, jóindulatú, érzékeny. Legelőnyösebb tulajdonsága, hogy képes megfelelően reagálni különböző személyiségü emberekre és helyzetekre, erősíti a csapatszellemet. Megbocsátható gyengesége, hogy kritikus helyzetekben határozatlan, esetleg leblokkol.

Megvalósitó (ME): Precíz, rendes, lelkiismeretes, szorongó. Legelőnyösebb tulajdonsága, hogy képes a feladatokat végigvinni, és mindemellett a tökéletességre törekszik. Elnézhető hibája, hogy csekélységek miatt is aggódik, nem képes hagyni, hogy a dolgok menjenek a maguk útján. Nem tudja elengedni magát (Belbin 1998).

„Újabban Belbin ezekhez a szerepekhez kilencedikként hozzáveszi a Szakértöt, aki egy bizonyos területen rendkívül nagytudású, de csak ezen a területen képes hasznossá tenni magát a csapatban." (Klein 2016).

A fenti típusok és tulajdonságaik leírásához kapcsolódóan az alábbiakban néhány közelmúltban végzett, hazai kutatás eredményei kerülnek bemutatásra. Egy 2017-ben publikált vizsgálat eredményei alapján az értékesítők szerint egy sikeres üzletkötőnek leginkább a következő három tulajdonoságokkal kell rendelkeznie: személyes kapcsolatok építésének képessége, az értékesítés és a kapcsolatok élvezete, önbizalom, míg a vevők véleménye alapján a becsületesség, a kapacitásigények kezelése és termékismeret megléte elengedhetetlen (Dankó \& Kovács 2017). Amennyiben a pénzügyi, biztosítási tevékenység nemzetgazdasági ágban dolgozó értékesítőkre fókuszálunk, akkor megállapítható, hogy az ezen a területen dolgozó értékesítők - a korábban, a magyar lakosságon standardizált rövidített Karliforniai Pszichológiai Kérdőív alapján elért értékekhez képest - a szociabilitás és a teljesítmény elérés konformizmus útján dimenziókban nyújtanak kimagasló eredményeket (Juhász 2019a). Motivációjukkal kapcsolatban pedig elmondható, hogy az „értékesítők motiválásában tehát olyan higiénés tényezőknek kell, hogy nagyobb szerep jusson, mint például a munka biztonsága, a tekintély, a munkakörülmények javítása, esetleg a tanulási, előmeneteli alternatívák tárházának bővítése” (Juhász 2019b).

A kutatásban alkalmazott kérdőív (Belbin 1998, Gyökér 2006) kitöltése során a vizsgálati személyeknek egy ötfokozatú skálán kellett eldönteniük, hogy az adott állítás mennyire igaz önmagukra nézve, ahol a nulla az egyáltalán nem jellemzö, a négyes a rendkívül jellemző értéket jelentette a skálán.
PÉNZÜGYI TERÜLETEN DOLGOZÓ ÉRTÉKESÍTŐK TÍPUSA A BELBIN-FÉLE CSAPATTAGTÍPUS KÉRDŐÍV ALAPJÁN (KUTATÁSI EREDMÉNYEK, KÖVETKEZTETÉSEK, JAVASLATOK) PERSONALITY PROFILE OF FINANCIAL SALES ASSOCIATES ACCORDING TO THE BELBIN TEAM ROLE QUESTIONNAIRE (RESEARCH RESULTS, CONCLUSIONS, RECOMMENDATIONS)

A hivatkozott szakirodalmak áttekintése, valamint a vonatkozó kutatások eredményei alapján arra számítottam, hogy a pénzügyi, biztosítási tevékenység nemzetgazdasági ágban dolgozó értékesítők többsége a Belbin-féle csapattagtípus kérdőív eredményeinek tükrében a Serkentő típusba fog tartozni. A fentiek alapján így a következő hipotézist fogalmaztam meg:

H1: A pénzügyi, biztositási tevékenység nemzetgazdasági ágban dolgozó értékesitôk többsége a Belbin-féle csapattagtipus kérdöiv eredményeinek tükrében a Serkentö típusba tartozik.

A kutatásban részt vevő válaszadók a Belbin-féle csapattagtípus kérdőív alapján három típusnál értek el 18 pont feletti értéket (1. ábra). Az átlageredmények tekintetében így a következő három csapattagtípus került a dobogóra: Vállalatépítő $(19,60)$, Csapatépítő $(18,78)$, Forrásfeltáró $(18,62)$. Az előzetes várakozásaim szerint itt a Serkentő $(17,82)$ típus érte volna el a legmagasabb pontértéket, amely „csak” a negyedik helyen végzett. A legalacsonyabb átlagos pontérték alapján a Palánta $(15,79)$ került a sereghajtó pozícióba. 


\section{1. ábra: A válaszadók Belbin-féle kérdőiv alapján elért átlageredményei \\ csapattagtípusonként (pont; $\mathrm{N}=1000$ )}

Figure 1. The average of the respondents's scores on the Belbin Team Role questionnaire according to type (expressed in points; $N=1000$ )

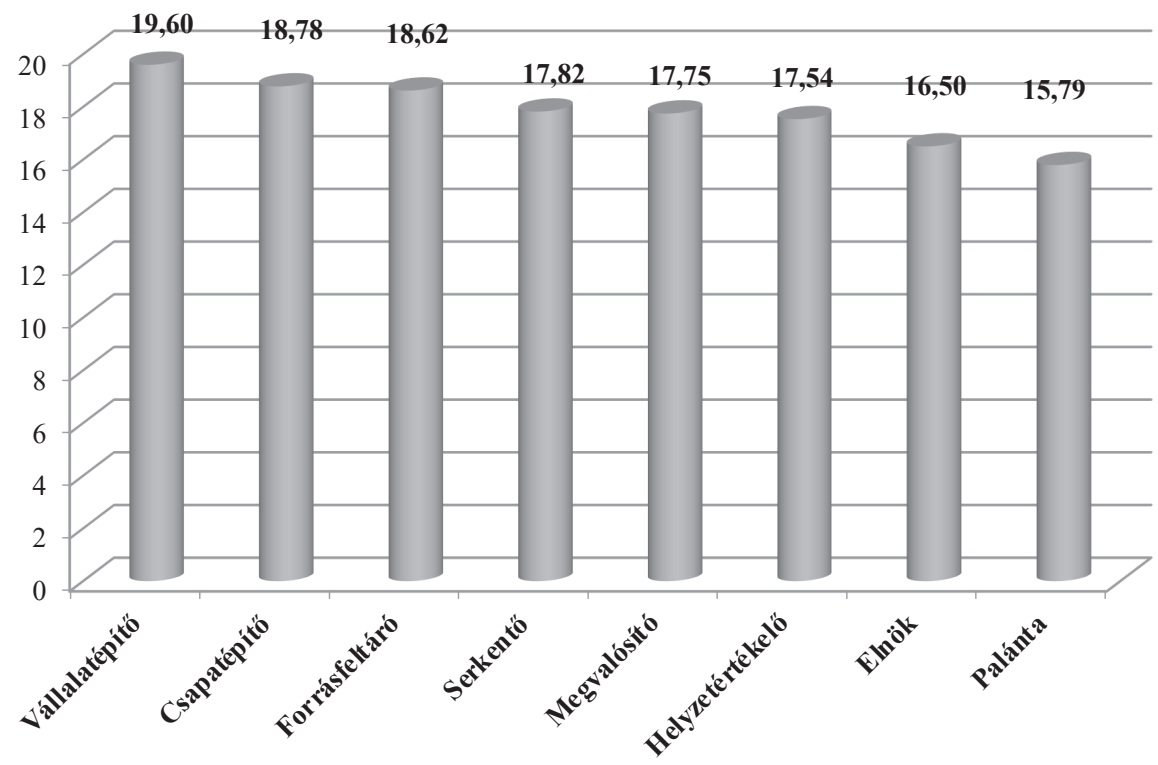

Forrás: saját számitás alapján

Az eredmények megvizsgálásra kerültek oly módon is, hogy kiderüljön, melyik csapattagtípusba mennyi üzletkötö tartozik. Egy üzletkötő több típusba is bekerülhetett abban az esetben, ha több típusban is maximális pontértéket ért el. Ilyen pontértéket az értékesítők összesen 1504 esetben értek el, mely típusok közötti megoszlását a 2. ábra hivatott bemutatni. Az átlageredményekhez képest a sorrend megegyezik, annyi eltéréssel, hogy a
Palánta és Elnök típusok sorrendje felcserélődött. A legnagyobb elemszámmal rendelkező kategóriáknak a teljes, 1504 elemszámú csapattagtípusmintához viszonyított megoszlása a következő: Vállalatépítő - $26 \%$, Csapatépítő - $19 \%$ és Forrásfeltáró $-15 \%$. 
2. ábra: A válaszadók Belbin-féle csapattagtípusok szerinti csoportosítása (fö; N=1000)

Figure 2. The categorisation of the respondents according to the Belbin Team Role questionnaire (per capita; $\mathrm{N}=1000$ )

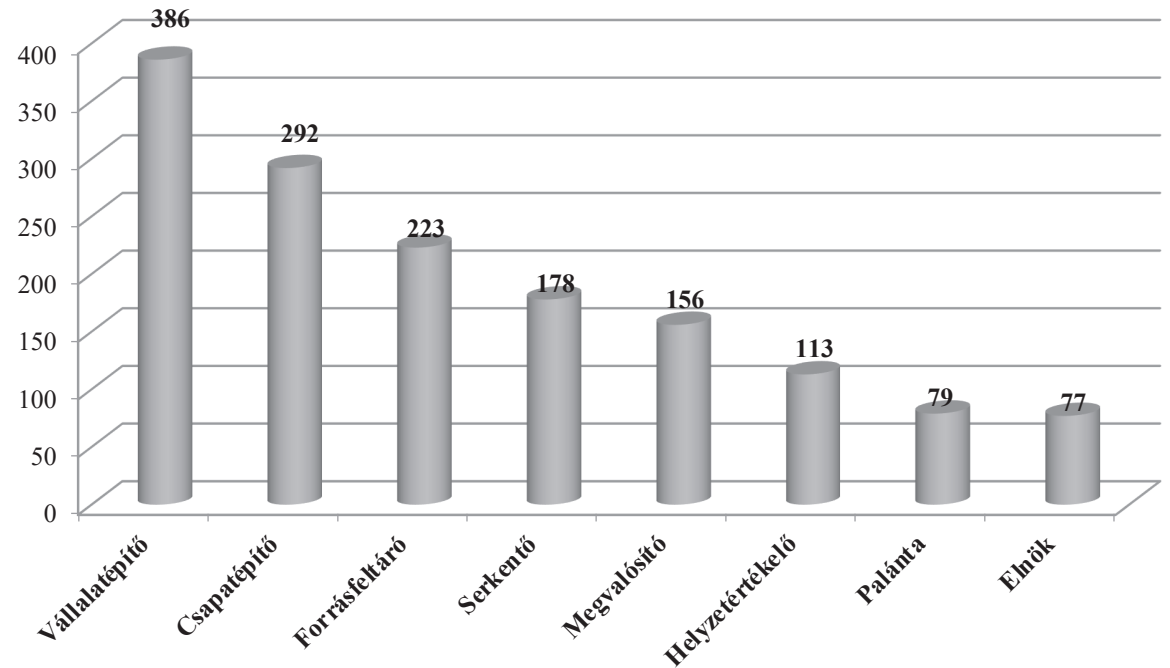

Forrás: saját számitás alapján

A mintavétel szempontjából kiemelten fontos négy legnépesebb ágazat esetében az egyes csapattagtípusok megoszlásáról (3. ábra) elmondható, hogy az ágazatok képviselöi közül a következő három esetben a Vállalatépítő kategóriában kerültek a legtöbben (zárójelben a Vállalatépítő típus \%-os megoszlása az adott ágazat képviselői között): lakástakarékpénztár (32\%), biztosítás (26 $\%)$, pénzügyi tanácsadás (26\%). Egyedül a banki ágazat képviselöi között ért el első helyezést a Csapatépítő típus (24\%) igaz, hogy szorosan követi azt Vállalatépítő társa (22\%).

A Vállalatépítő kategória ilyen horderejü „térhódítása" nem volt várható, bár a típus jellemzőinek leírása több olyan kompetenciát is tartalmaz, mely elengedhetetlen a pontos, precíz, a pénzügyi, biztosítási tevékenység nemzetgazdasági ágban méltán megkövetelt munkavégzéshez, mivel ez a típus kötelességtudó, kiszámítható és konzervatív. Legföbb hasznos tulajdonsága, hogy jó szervező, gyakorlatias gondolkodású, keményen dolgozik, és nagyon fegyelmezett. Megbocsátható gyengesége, hogy rugalmatlan és kevésbé fogékony az új ötletekre (Belbin 1998).
A négy vizsgált ágazat közül három esetében a Csapatépítő típus került a második helyre: lakástakarékpénztár (19\%), biztosítás (16\%), pénzügyi tanácsadás (16\%), első helyezést pedig a már említett banki ágazat képviselöi között ért el. A típus jellemzésében sok olyan tulajdonság található, mely szintén fontos feltétele lehet a sikeres munkavégzésnek egy pénzügyi területen dolgozó értékesítő esetében, mivel ez a típus társas hajlamú, barátságos, jóindulatú, érzékeny. Legelőnyösebb tulajdonsága, hogy képes megfelelően reagálni különböző személyiségủ emberekre és helyzetekre, erősíti a csapatszellemet. Megbocsátható gyengesége, hogy kritikus helyzetekben határozatlan, esetleg leblokkol (Belbin 1998). 
3. ábra: A válaszadók Belbin-féle csapattagtípusok szerinti csoportosítása a pénzügyi, biztosítási tevékenység nemzetgazdasági ág, ágazatai szerint (fö; $\mathrm{N}=1000$ )

Figure 3. The categorisation of the respondents according to the Belbin Team Role questionnaire by financial sales associates of the finance and insurance sector (per capita; $N=1000$ )

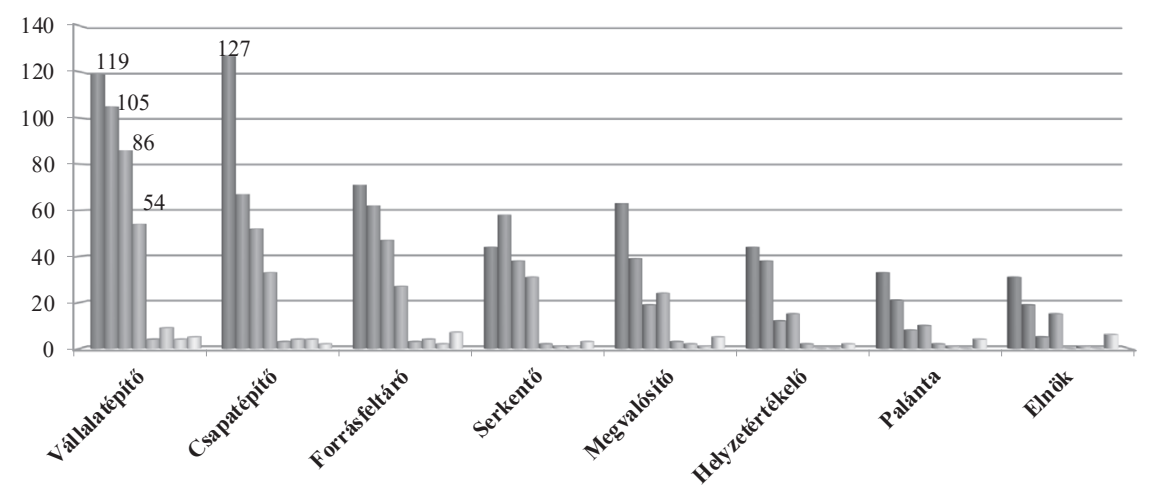

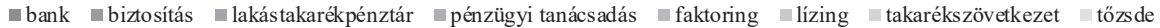

Forrás: saját számitás alapján

A vizsgált mintának a Belbin-féle csapattagtípus kérdőívben elért eredményein végzett megoszlások kiszámítása alapján a tehát a következőket állítom: a vizsgált, pénzügyi területen dolgozó üzletkötők közül a Belbin-féle csapattagtípus kérdőívben elért eredmények alapján legtöbben a Vállalatépítő típusba (a teljes minta $26 \%$ ) tartoznak. Magas értéket ért még el a Csapatépítő típus (19\%) és a Forrásfeltáró típus (15\%). A három típusba történő besorolás, összesen a minta $60 \%$-át fedi le. A H1 hipotézist tehát elvetem.

A kutatási eredmények alapján javaslom, hogy a pénzügyi területen tevékenykedő értékesítők kiválasztásában a Belbin-féle csapattagtípus kérdőív eredményeinek tükrében elsősorban a Vállalatépítő, Csapatépítő és Forrásfeltáró csapattagtípusokba történő besorolást tekintsék - szükséges, de nem elégséges - pozitív feltételnek a vállalati döntéshozók és HR szakemberek. Külön szeretném itt kiemelni a Vállalatépítő típus jelentőségét. A kutatás során ugyanis az elért legmagasabb teljesítmény - amit jelen esetben az elért éves bruttó jövedelem aposztrofál - és az egyes szerepek közötti összefüggés is vizsgálatra került. Amenynyiben az értékesítők jövedelmét is figyelembe vesszük, akkor a mintában szereplő 1000 üzletkötő közül 33 fó éves jövedelme haladja meg a bruttó 10 millió forintot és közülük 19 értékesítő kerül a Vállalatépítő típusba. A mintában szereplö értékesítők közül tehát nemcsak a legtöbb, de - legalábbis az anyagiak terén - a legeredményesebb üzletkötö is a Vállalatépítő típusba tartozik.

\section{ÖSSZEFOGLALÁS SUMMARY}

Tanulmányom megírásával az volt a célom, hogy bemutassam, lehetőség szerint mely Belbin-féle csapattagtípusba kell tartoznia a jelenkor üzletkötöinek ahhoz, hogy munkájukat sikeresen végezzék. Az üzletkötők és értékesítők körét leszükítettem a pénzügyi, biztosítási tevékenység nemzetgazdasági ág területére, mivel szélesebb területen dolgozó üzletkötők típusvizsgálata meghaladta volna ezen tanulmány keretét.

A felsorolt vizsgálati eredmények alapján az üzletkötői posztra jelentkező személyek esetében már az első személyes találkozó, interjú előtt - akár egy online módon kitölthető kérdőív segítségével fel lehet térképezni a jelölt csapattagtípusát, illetve ebből fakadó személyiségét, habitusát, értékeit, motivációit, kompetenciáit. Amennyiben beleillik a fentiekben vázolt profilokba, úgy érdemes a kiválasztást végző szakembernek tüzetesebb vizsgálatok alá vetni a jelentkezőt. Az eredmények tükrében a személyzeti-, értékesítési vezető eldöntheti, hogy érdemes-e felvenni a szervezethez az adott 
pályázót vagy sem. Amennyiben érdemes, akkor időt, energiát és pénzt nem sajnálva ki kell képezni az új kollégát oly módon, hogy mindkét fél kölcsönös megelégedettségére végezze munkáját. Sok konfliktus és későbbi csalódás előzhető meg azáltal, hogy a fentieket követve a megfelelö embert veszi fel a vezető a megfelelö értékesítői posztra és nem csak a személyes szimpátia alapján próbálja meg betölteni az üres álláshelyeket.

A kutatási eredmények alapján javaslom, hogy a pénzügyi területen tevékenykedő értékesítök kiválasztásában - illetve későbbi motiválásában - alkalmazandó Belbin-féle csapattagtípus kérdőív eredményei esetében elsősorban a következő csapattagtípusokba történő besorolást tekintsék szükséges, de nem elégséges - pozitív feltételnek a vállalati döntéshozók: Vállalatépítő, Csapatépítő és Forrásfeltáró! Végezetül pedig álljon itt Klein Sándor professzor úrtól egy rövid, de lényegbevágó és az értékesítés lényegét (is) jól meghatározó idézet. A vállalaton belüli tekintély megszerzéséhez ugyanis a pozíció - sok más olyan tényező mellett, mint például a megfelelő személyiségjellemzők vagy akár a kívánt csapattagtípus megléte - önmagában kevés, ha nem párosul hozzá motivált munkavégzés: „Az az igazság, hogy tényleges tekintélyt szerezni ma már nem a szervezeti rendszerben betöltött minél magasabb pozícióval, hanem a fogyasztó érdekében végzett, magas színvonalú munkával lehet" (Klein 2016, 588).
${ }^{1} \mathrm{~A}$ tanulmányhoz kapcsolódó vizsgálat körülményei és módszertana szükségszerüen megegyezik más - a doktori kutatáshoz kapcsolódó - publikációk vizsgálati körülményeivel és módszertanával, további komponensei azonban nem. 


\section{HIVATKOZÁSOK REFERENCES}

Baranyi A., Czibolya B., Csernák J. (2019), „A tudás megtérülésének vizsgálata egy primer vizsgálat eredményei alapján", Gradus 6(3), 44-49 http://real.mtak.hu/109447/ Utolsó letöltés: 2020.07.07.

Belbin, M. (1998), A team, avagy az együttmüködö csoport, Budapest: SHL Hungary

Dankó L., Kovács P. (2017), „Elégedettségfókuszú személyes értékesítés B2B üzleti kapcsolatokban", in: Piskóti I. (szerk.), Marketingkaleidoszkóp 2017, Miskolc: Miskolci Egyetem - Gazdaságtudományi Kar, Marketing és Turizmus Intézet, 9-37 http://midra.uni-miskolc.hu/ document/30310/26310.pdf Utolsó letöltés: 2020.07.02.

Effron, M., Gandossy, R., Goldsmith, M. (2003), Managing Human Resources in the 21st Century, Wiley: Hoboken

Fombrun, C. J., Tichy, N. M. and Devanna, M. A. (1984), Strategic Human Resource Management, New York: John Wiley

Gyökér I. (2006), Szervezeti viselkedés - Tesztek - Oktatási segédanyag, Budapest: Budapesti Műszaki és Gazdaságtudományi Egyetem, Menedzsment és Vállalatgazdaságtan Tanszék, MBA program

Juhász I. (2019a), „Pénzügyi területen dolgozó értékesítők személyiségvizsgálata", Pénzügyi Szemle, LXIV. évfolyam, 2019(2), 175-190 https://www.penzugyiszemle.hu/documents/ juhaszi-2019-2-mpdf_20190704135952_17.pdf Utolsó letöltés: 2020.07.02.

Juhász I. (2019b), ,Értékesítői motivációk-Különös tekintettel a pénzügyi, biztosítási tevékenység nemzetgazdasági ágra", Vezetéstudomány, 50(7-8), 39-48 http://unipub.lib.uni-corvinus. hu/4136/ Utolsó letöltés: 2020.07.02. DOI: 10.14267/VEZTUD.2019.07.04

Karoliny M. (2009), „Erőforrás-biztosítás: toborzás, kiválasztás, leépítés”, in: Farkas F., Karoliny M., László Gy., Poór J. (szerk.), Emberi eröforrás menedzsment kézikönyv, Budapest: CompLex Kiadó Jogi és Üzleti Tartalomszolgáltató Kft., 155-181

Karoliny M., Poór J. (2017), „Bevezetés”, in: Karoliny M., Poór J. (szerk.), Emberi erőforrás menedzsment kézikönyv - Rendszerek és alkalmazások, Budapest: Wolters Kluwer Hungary Kft., 19-21

Klein S. (2016), Vezetés- és szervezetpszichológia, Budapest: SHL Könyvek
Kozák A. (2015), Munkahelyi beillesztés nagyvállalati környezetben, Debrecen: PhD értekezés, Debreceni Egyetem, Ihrig Károly Gazdálkodás- és Szervezéstudományok Doktori Iskola https://dea.lib.unideb.hu/dea/bitstream/ handle/2437/208721/Kozak_Anita_PhD_ ertekezes_titkositott.pdf? sequence $=1 \&$ isA1lowed=y Utolsó letöltés: 2020.07.07.

Kővári Gy. (1991), Gazdálkodás az emberi eröforrásokkal, Budapest: Országos Munkaügyi Központ

Matiscsákné L. M. (2014), „Toborzás és kiválasztás", in: Juhász I. - Matiscsákné L. M. (szerk.), Emberi-eröforrás gazdálkodás, Főiskolai tankönyv, Információtechnológia MA képzéshez, (TÁMOP-4.1.2.A/1-11/1). 2014., Eger: Eszterházy Károly Főiskola, Líceum Kiadó, 83-98

Nemeskéri Gy. (2013), „A kiválasztási eljárások megbízhatósága”, Munkaügyi Szemle, 57(4), 80-89

Szabó K., Tanyik G. E., Csernák J. (2017), „Az Y generáció és a nemzetközi kiküldetések", Acta Carolus Robertus, Gyöngyös: Eszterházy Károly Egyetem, Gyöngyösi Károly Róbert Campus, 7(2), 181-202 Utolsó letöltés: 2020.07.07. DOI: 10.22004/ag.econ.265787

Szőts-Kováts K. (2007), „Munkaerő áramlás“, in: Bokor A., Szőts-Kováts K., Csillag S., Bácsi K., Szilas R. (szerk.), Emberi Eröforrás Menedzsment, Budapest: AULA Kiadó, 133-172

Töttős Gy. (2005), Az értékesitő profil a gyógyszeriparban (Az orvoslátogatói pályaprofil elemzése és vizsgálata), Szeged: Szegedi Tudományegyetem, Bölcsészettudományi Kar

Zöllei K. (2006), „Felvétel indul! Új típusú elvárások a toborzás-kiválasztásban", $H R$ Portal, https://www.hrportal.hu/hr/felvetel-indul-uj-tipusu-elvarasok-a-toborzas-kivalasztasban-20060713.html Utolsó letöltés: 2020.07.02. 
Juhász István, $\mathrm{PhD}$, adjunktus juhasz.istvan@uni-eszterhazy.hu

Eszterházy Károly Egyetem

\section{Financial sales associates in the light of the Team Role survey}

\section{THE AIM OF THE PAPER}

The basic purpose of my essay is the construction of a team role for financial sales associates via the Belbin Team Role survey facilitating the selection and the motivation of the best candidates for sales personnel in the financial and insurance sector of the national economy.

\section{METHODOLOGY}

The inquiry focused on the personal features of financial sales associates working in banks, insurance companies, residential savings, financial consultancy firms, factor and leasing firms, savings banks, and stock brokerages. I opted for the on-line version of the questionnaires. Instead of random sampling I followed the snowball principle as actual sample members recruited future participants for the sampling process. The collected data was analyzed and evaluated by excel program. The average of the sample was established from various aspects along with the use of frequency and distribution ratios.

\section{MOST IMPORTANT RESULTS}

The majority of the financial sales associates belong to the Implementer type ( $26 \%$ of the full sample). Furthermore the Teamworker and Resource investigator category achieves high scores with $19 \%$ and $15 \%$ respectively. The respective ranking represents $60 \%$ of the sample. Respondents participating in the research achieved higher than 18 points in also these three categories of the Belbin questionnaire. The top three types are Implementer $(19,60)$ Team worker $(18,78)$, and Resource investigator $(18,62)$.

\section{RECOMMENDATIONS}

The selection and the motivation of financial sales personnel should also utilize the Belbin type team membership questionnaire. The following categories and traits should be regarded necessary and positive, but not sufficient hiring criteria: Implementer, Teamworker, Resource investigator.

Keywords: sales associates, finance sector, insurance sector, Team Role survey 